\title{
Article \\ Influence of the Thickness of Scots Pine (Pinus sylvestris L.) Veneers on Selected Properties of Flooring Materials
}

\author{
Piotr Beer ${ }^{1}$, Paweł Pacek ${ }^{2}$ and Izabela Burawska-Kupniewska ${ }^{1, *(D)}$ \\ 1 Institute of Wood Sciences and Furniture, Warsaw University of Life Sciences-SGGW, Nowoursynowska 159, \\ 02-776 Warsaw, Poland; piotr_beer@sggw.edu.pl \\ 2 Stolarstwo Pacek, Sufczyn 47, 05-340 Kołbiel, Poland; ppoipawel@gmail.com \\ * Correspondence: izabela_burawska@sggw.edu.pl
}

check for updates

Citation: Beer, P.; Pacek, P.; Burawska-Kupniewska, I. Influence of the Thickness of Scots Pine (Pinus sylvestris L.) Veneers on Selected Properties of Flooring Materials. Forests 2022, 13, 175. https:// doi.org/10.3390/f13020175

Academic Editor: Brian K. Via

Received: 22 November 2021

Accepted: 21 January 2022

Published: 24 January 2022

Publisher's Note: MDPI stays neutral with regard to jurisdictional claims in published maps and institutional affiliations.

Copyright: (C) 2022 by the authors. Licensee MDPI, Basel, Switzerland. This article is an open access article distributed under the terms and conditions of the Creative Commons Attribution (CC BY) license (https:// creativecommons.org/licenses/by/ $4.0 /)$.

\begin{abstract}
The aim of our study was to analyze the influence of the thickness of Scots pine veneers on the chosen physical and mechanical properties of plywood-like composites dedicated to flooring applications. The utilitarian goal of the research is to replace three-layer flooring requiring high production costs with flooring materials of much cheaper (lower number but thicker veneers) and less specialized production. The only variable in the presented research is the thickness of the veneer creating the structure of the base layer of flooring materials. If we take into account that the number of veneers in the base layer can be reduced, it is the best way to reduce the number of materials (especially adhesives), to protect the environment. The research was conducted regarding basic mechanical properties that determine the suitability of flooring materials: modulus of elasticity, stiffness, and bending strength. The cross arrangement of the veneers in the tested samples in the base layer showed high values of the modulus of elasticity and stiffness. These values are higher than for three-layer commercially available composites. Despite the fact that the research was of pilot character, the results indicate a large potential for saving raw wood and for increasing the productivity of enterprises. The flooring materials were tested, but the test results are relevant in other applications built on materials with veneers in the form of plywood-like structure.
\end{abstract}

Keywords: flooring; properties; veneer; thickness; plywood-like materials

\section{Introduction}

The optimization of production processes is an important element of the strategy of a given company. One of the methods of increasing the efficiency is changing the production parameters, including the automation of production processes, increasing the qualifications of the staff, as well as introducing process and product innovations. Wood is still a popular material used in floor production in the interior construction of houses, flats, and some public places, but especially of palace and manor floors. However, for popular applications, floors are often constructed using wood composites [1-3]. Commercially available are mainly wood composites of two- and three-layer structures [4-6]. Two-layer flooring structures are made of a face layer on the top and a base layer as the substructure. In three-layer flooring structures, apart from the top layer, the base layer is composed of an inner layer and a bottom layer. The layered construction makes it possible to use various materials in the face and base layers in the form of thin wooden slats or veneers. Species meeting requirements of the face layers are often used: oak (Quercus robur L.), ash (Fraxinus excelsior L.), doussie (Afzelia Africana Pers.), and sapele (Entandrophragma cylindricum Sprague). The base layers are built from readily available materials with low density and low mechanical properties, for example in Europe, pine (Pinus sylvestris L.), spruce (Picea excelsa L.), and fir (Abies alba Mill.). Because the face layers are the most important part of flooring from a functional and aesthetic point of view, the main research trends concerning floors relates to the surface properties of the face layers. They are built from solid 
or glued wood, as two-strip or three-strip. Thus, this kind of research is focused on testing the properties of the top layer and is conducted on separated face layers material (without base layer) or on the face layer as a part of flooring. The research may include exposition to temperature and humidity [7], hardness [8-10], strength [11], top-layer examination after material modifications [12-14], or in situ polymerization of active monomers [15]. The study of entire flooring materials focuses on connection with heating systems [16-20] or using individual wood species or quality for flooring applications. Research on the physical and mechanical properties of floor composites for floating floors and sports floors is mainly conducted in view of their elastic properties [21]. It is possible to verify the dynamic parameters for rebound height of a ball bouncing off a rigid floor. Additionally, the application of FEM modeling gives the opportunity to design sports floor structures of various structural and material solutions for sports flooring more easily and holistically. Kallakas et al. [22] verified the influence of different hardwood species and lay-up schemes on the mechanical properties of plywood. The research they conducted showed that, depending on wood species, plywood has different bending strength or glue consumption, and it was shown that combination of wood species is a method enabling to obtain more durable and stronger plywood. Similar conclusions were drawn by Beer et al. [23] when layered composites were produced with combination of alder (Alnus glutinose Gaerth.) and Scots pine (Pinus sylvestris L.). In this case, modulus of elasticity and stiffness in bending for combined plywood-like composites were higher than made from only Scots pine veneers.

Research on the influence of quality of veneers on the final product was studied for laminated veneer lumber (LVL). It has been observed that the application in the outer layer of LVL of higher quality (defect-free) veneer provides more favorable mechanical properties. When a large number of low-quality veneers were applied in the middle layer of LVL, lower strength parameters were obtained [24]. When analyzing the quality of individual veneer (A-the highest, D-the lowest) $[25,26]$, increased physical and mechanical properties of engineered flooring material were obtained only in the case of application veneers of class $A$, whereas the other veneer quality classes $(B, C, D)$ did not significantly influence the strength parameters of layered composite. It is possible to use veneers of lower quality classes $(\mathrm{B}, \mathrm{C}, \mathrm{D})$ for flooring production without verification of which class they belong to. It would significantly reduce the production time and operation costs.

Layout of layered structure on the physical and mechanical properties were taken into account in research performed by Lee et al. [27]. Various arrangement of the moso bamboo (Phyllostachys edulis) structure was analyzed - parallel-layered and cross-layered. Cross-laminated composites showed the highest values of MOE and MOR in relation to other parallel-layered structures, which is connected to the arrangement of the fibers in relation to the loading direction.

The presented work deals with two-layer flooring with base layer of plywood-like structure. This is wood-based material that has a layered cross-shaped construction resulting in a greater dimensional stability and strength of the structure, even if it is exposed to permanent loads, for example, the pressure of furniture and/or cyclical loads, such as foot traffic. In addition, this composite is easy to assemble. The aim of our study was to analyze the influence of the thickness of Scots pine veneers on the chosen physical and mechanical properties of plywood-like composites dedicated to flooring applications. The utilitarian goal of the research is to replace three-layer commercial flooring requiring high production costs with flooring of much cheaper and less specialized production based on application of lower number of, but thicker, veneers. The structure of the base layer creates the possibility of faster, i.e., more efficient, production.

\section{Experimental Tests}

\subsection{Materials}

As the presented work deals with two-layer flooring material with base layer of plywood-like structure, thin oak (Quercus robur L.) slats were glued on the top of a crossshaped Scots pine (Pinus sylvestris L.) base layer (Figure 1). Oak slats with a thickness of 
$3 \mathrm{~mm} \pm 0.2 \mathrm{~mm}$ were of the highest wood quality (A) [25] and supplied by the Barlinek Group enterprise in Poland [28]. Scots pine veneers were supplied by Paged Morag S.A. in Poland [29], in class A quality and three thickness variants $(1.5 \mathrm{~mm} \pm 0.1 \mathrm{~mm}$, $2.5 \mathrm{~mm} \pm 0.1 \mathrm{~mm}$, and $3.2 \mathrm{~mm} \pm 0.1 \mathrm{~mm}$ ). The use of material of the same quality ensured variability in tests of only one factor-thickness of the veneers. The mean value of modulus of elasticity for oak wood was 11,700 MPa and for Scots pine material it was 12,000 MPa, and the static bending strength was 88 and $100 \mathrm{MPa}$, respectively [30].

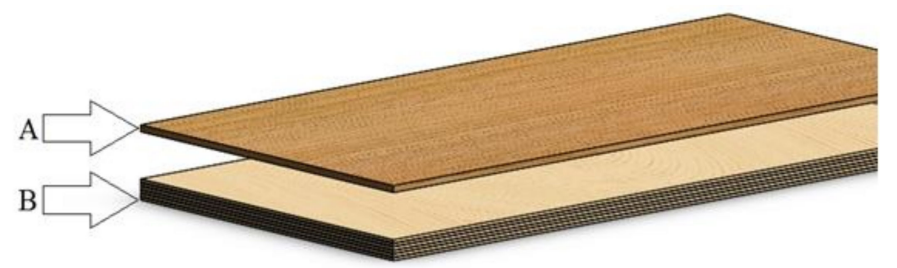

Figure 1. Structure of the flooring material: A — the face layer made of oak slat, B-the plywood-like base layer made of Scots pine veneers.

The Scots pine veneers were cut circumferentially (by rotary cutting) to $350 \mathrm{~mm} \times 180 \mathrm{~mm}$ in such a way that the even layers had fibers arranged perpendicular to the length of the composite $(\perp)$, thus the odd layers had fibers arranged parallel to the length of the samples $(=)$. The samples prepared in this way had veneers arranged according to the scheme presented in Table 1. The 11 samples from each group were prepared for static and dynamic bending tests.

Table 1. Samples layout scheme.

\begin{tabular}{|c|c|c|c|c|c|c|c|}
\hline \multirow{2}{*}{$\begin{array}{l}\text { Samples } \\
\text { Mark }\end{array}$} & \multirow{2}{*}{$\begin{array}{c}\text { Oak Layer (mm) } \\
=\end{array}$} & \multicolumn{6}{|c|}{ Scots Pine Veneers in the Base Layer (mm) } \\
\hline & & $\perp$ & $=$ & $\perp$ & $=$ & $\perp$ & $=$ \\
\hline Thick 1 & 3 & 2.5 & 3.2 & 2.5 & 3.2 & - & - \\
\hline Thick 2 & 3 & 3.2 & 3.2 & 3.2 & 3.2 & - & - \\
\hline Thin & 3 & 1.5 & 2.5 & 1.5 & 2.5 & 1.5 & 2.5 \\
\hline
\end{tabular}

$(\perp,=)$-The arrangement of the fibers in relation to the length of the sample.

The thicknesses of the veneers were selected so that the engineering flooring material has a similar final thickness, and taking into account technological issues, so that the damage of the thick veneers during peeling (rotary cutting) was as small as possible. In peeling, one of the main disadvantages of this process are cracks inside the veneer from the side of the cutting knife [31]. It results from the mechanism of the cutting process, in which the wood material is tensioned from the side of the cutting knife, and it is tensioned perpendicularly to the direction of the fibers. The thicker the veneer, the bigger the cracks, which can lead to a complete fracture of the veneer. Other defects in peeling are uneven veneer thickness, waviness, and surface roughness. The largest selected veneer thickness $(3.2 \mathrm{~mm})$ was a compromise between the cutting (production) speed (with other parameters constant) and the number and depth of the defects. Urea formaldehyde adhesive Akzo Nobel 1274 was used to bond the composite elements. This resin has a viscosity of approximately $3000 \mathrm{MPa} \cdot \mathrm{s}$, dry content of $67-70 \%$, and density around $1100 \mathrm{~kg} / \mathrm{m}^{3}$.

The composition and properties of the adhesive resin constitute the know-how of the manufacturer of layered floors. Due to the lack of a safety data sheet, the first step was to determine the hardening time of the adhesive mixtures, with the addition of $10 \%$ and $20 \%$ of hardener prepared (Table 2). The mixture was then immersed and stirred in a boiling water bath. Due to requiring the complex folding process of the composite, $10 \%$ hardener additive was applied. The adhesive application was $180 \mathrm{~g} / \mathrm{m}^{2}$. The pressing parameters were set as follows: 
- Pressing time-12 $\mathrm{min}$.

- $\quad$ Temperature- $120^{\circ} \mathrm{C}$.

- $\quad$ Pressure-1.2 MPa.

Table 2. Hardening time of the glue with a different percentage of hardener.

\begin{tabular}{cccc}
\hline Test & Adhesive (g) & Hardener (g) & Hardening Time (s) \\
\hline 1 & 100 & 10 & 60 \\
\hline 2 & 100 & 20 & 45 \\
\hline
\end{tabular}

After gluing, the composites were seasoned. The material was stored at a temperature of $22{ }^{\circ} \mathrm{C}$, and $50 \%$ relative humidity for 28 days. Then, the conditioning of the composites was carried out in a climatic chamber. The composites were placed on spacers and subjected to seasoning, simulating the behavior of the composites under various climatic conditions corresponding to the natural seasons of the year [32]:

- Winter time: temperature $22{ }^{\circ} \mathrm{C}, 10 \%$ air humidity for 28 days.

- Summer time: temperature $22^{\circ} \mathrm{C}, 80 \%$ air humidity for 28 days.

After seasoning time, the geometry of composites was verified with the use of a mechanical computer numerical control (CNC) plotter (ZEPWN, Marki, Poland) (Figure 2). The device verifies the geometry in a vertical position. The composites were supported at the base layer and the measurement was carried out on the top layer. The virtual measuring plane was fixed at three base points. The fourth point was adjustable to stabilize the test material during measurement. Measurement accuracy was $0.1 \mathrm{~mm} / \mathrm{m}$. Deviations from the theoretical plane of the composite surface were $\pm 1.5 \mathrm{~mm}$.

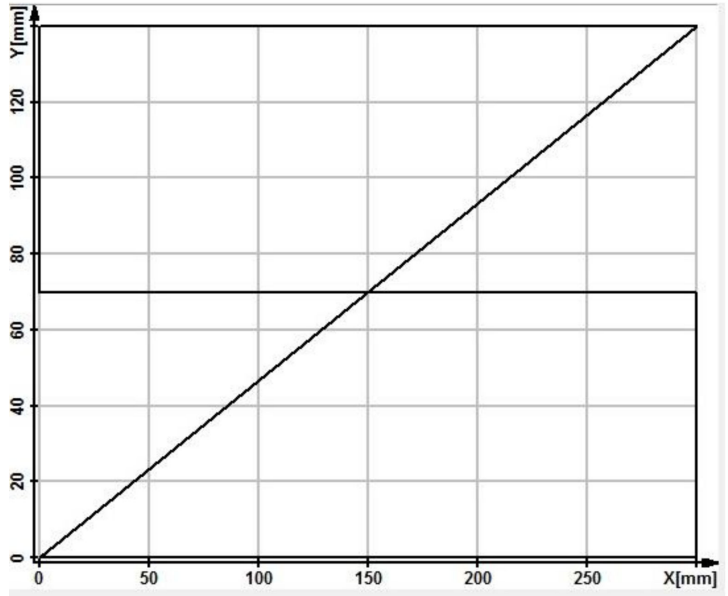

(a)

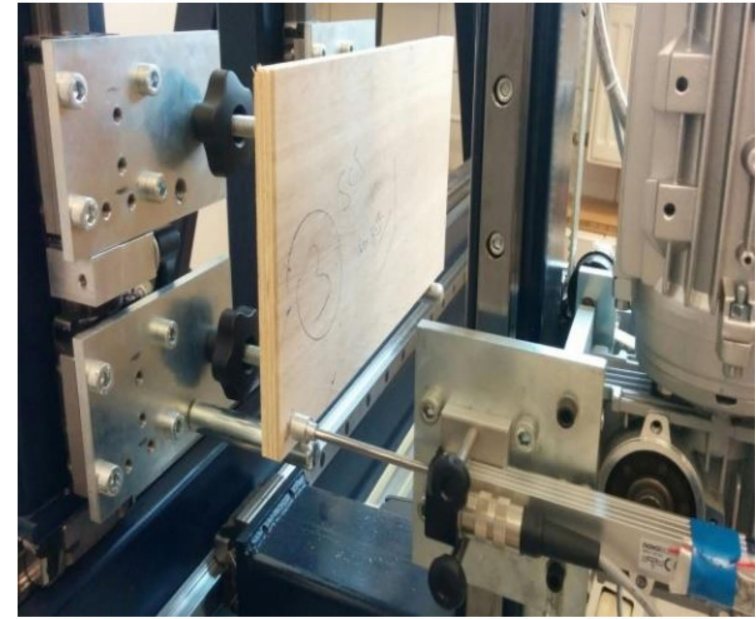

(b)

Figure 2. Geometry verification of the composites: (a)—measuring probe path diagram, (b)—during measurement.

Simultaneously with the verification of the geometry, the density profile was measured, which was carried out for composites seasoned in dry, normal, and humid conditions, using the Grecon device (Alfeld, Germany). For this purpose, three samples from each group of composite were prepared. The material with a cross-section of $50 \mathrm{~mm} \times 50 \mathrm{~mm}$ was measured with an electronic caliper with an accuracy of $0.01 \mathrm{~mm}$. The elements were weighed using a laboratory balance with an accuracy of $0.001 \mathrm{~g}$. The density profile was measured at a speed of $0.05 \mathrm{~mm} / \mathrm{s}$. 


\subsection{Methods}

\subsubsection{Tests of Bending}

The modulus of elasticity (MOE) for static, dynamic, and fatigue tests was determined based on the EN 310:1994 standard [33]. The experiment was carried out on a TiraTest 2300 testing machine (TIRA GmbH, Schalkau, Germany) in a three-point bending test (Figure 3).

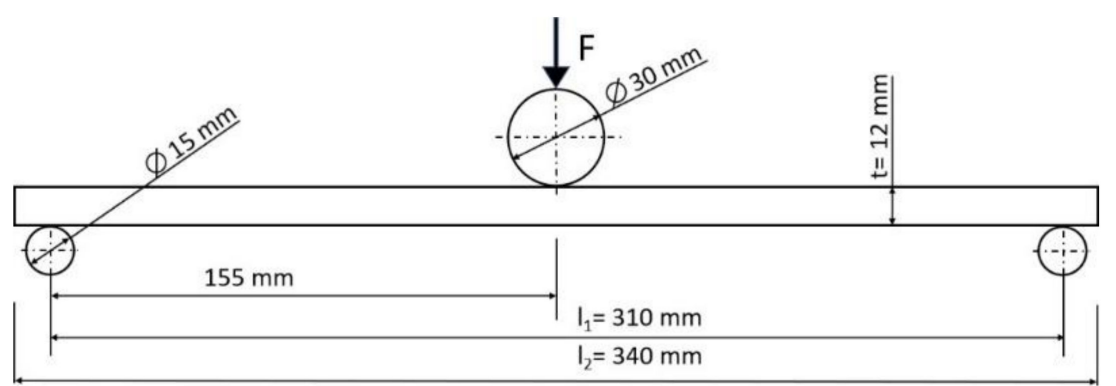

Figure 3. Arrangement of three-point bending test.

Formula (1) was used to calculate the modulus of elasticity in bending tests:

$$
E_{m}=\frac{L_{1}^{3}\left(F_{2}-F_{1}\right)}{4 b t^{3}\left(a_{2}-a_{1}\right)}
$$

where

Em (MPa) - modulus of elasticity, $\mathrm{L}_{1}(\mathrm{~mm})$ - distance between support centers, $\mathrm{F}_{2}-\mathrm{F}_{1}$ $(\mathrm{N})$ - load increase along the straight section of the curve, $\mathrm{F}_{1}(\mathrm{~N})-10 \%$ of load, $\mathrm{F}_{2}(\mathrm{~N})-40 \%$ of load, $b(\mathrm{~mm})$ - sample width, $\mathrm{a}_{2}-\mathrm{a}_{1}(\mathrm{~mm})$ - increase of the displacement arrow in the middle of the composite (corresponding to $\mathrm{F}_{2}-\mathrm{F}_{1}$ ).

The static bending strength was determined from Formula (2):

$$
\mathrm{f}_{\mathrm{g}}=\frac{3 \mathrm{~F}_{\max } \mathrm{L}_{1}}{2 \mathrm{bt}^{2}}
$$

where $f_{g}\left(\mathrm{~N} / \mathrm{mm}^{2}\right)$ —static bending strength, $F_{\max }(\mathrm{N})$-maximal force, $t(\mathrm{~mm})$ - sample thickness.

The verification of dynamic bending was aimed at determining whether the composite can be used in the conditions of floating floors and in the field of high dynamic loads, such as pavement in sports halls. The test consisted of a dynamic load application to the composite. The traverse speed was set to $9 \mathrm{~mm} / \mathrm{s}$, resulting from the maximum technical capabilities of the testing machine. After that, fatigue tests were performed with the speed of the traverse of $9 \mathrm{~mm} / \mathrm{s}$. The tested material was subjected to 50 cycles of dynamic load. Every first and tenth cycle was taken into account.

\subsubsection{Tests of Stiffness}

Stiffness is the ability of a material, connection, or structure to counteract deformations caused by external loads. It depends on the shape of the element, its elastic properties, type of load, and boundary conditions. The stiffness of composites under static and dynamic loading conditions was determined from Formula (3) [34]:

$$
\mathrm{k}=\frac{\mathrm{E}_{\mathrm{m}} \mathrm{bt}^{3}}{12}
$$

where $\mathrm{k}\left(\mathrm{MNmm}^{2}\right)$-stiffness. 


\section{Results and Discussion}

\subsection{Density Profile}

The density measurements (Figure 4) show that regardless of the relative air humidity condition, the density distribution is highly repeatable. Local density peaks reflect glue joints of increased density in relation to the density of the veneers. The thicker the veneers, the fewer the glue joints that have to be applied in the engineered flooring material. It is a step towards ecology and increasingly stringent environmental protection requirements, presented in subsequent guidelines and decrees of the European Commission [35-37].

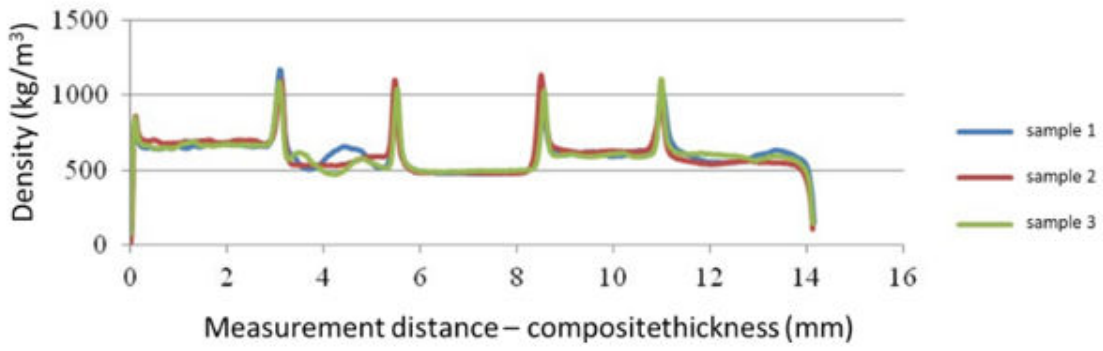

(a)

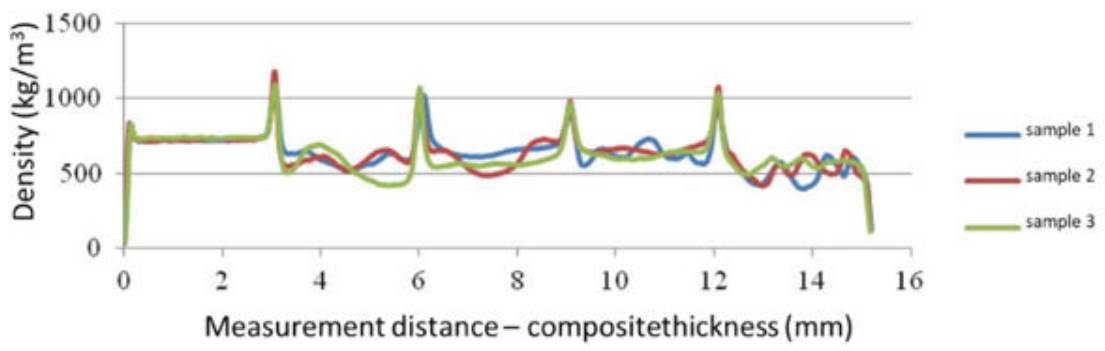

(b)

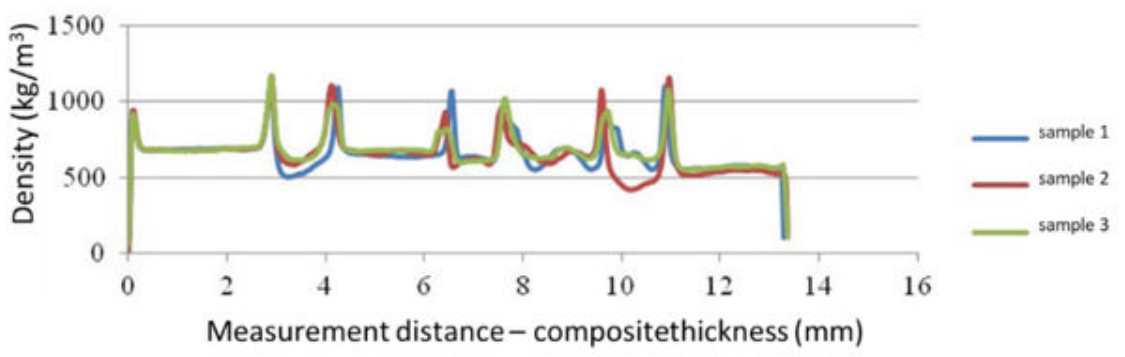

(c)

Figure 4. Density profiles of tested samples after air conditioning under conditions of $22{ }^{\circ} \mathrm{C}$ and $50 \%$ air humidity: (a) - group thick 1, (b) - group thick 2, (c) — group thin.

\subsection{Static Bending}

The results of testing the modulus of elasticity of individual samples are shown in Figure 5. The cross arrangement of the veneers in the tested samples in the base layer, regardless of the veneer thickness, caused relatively high values of the modulus of elasticity and stiffness. These values are higher than for three-layer commercially available composites characterized by MOE of $7200 \mathrm{MPa}$ and stiffness of $290 \mathrm{MNmm}^{2}$ [38,39]. Therefore, in the technology based on circumferential cutting, it is possible to use the veneers of higher 
thickness, i.e., $3.2 \mathrm{~mm}$, for production of engineered flooring material, and simultaneously to save time and production costs.

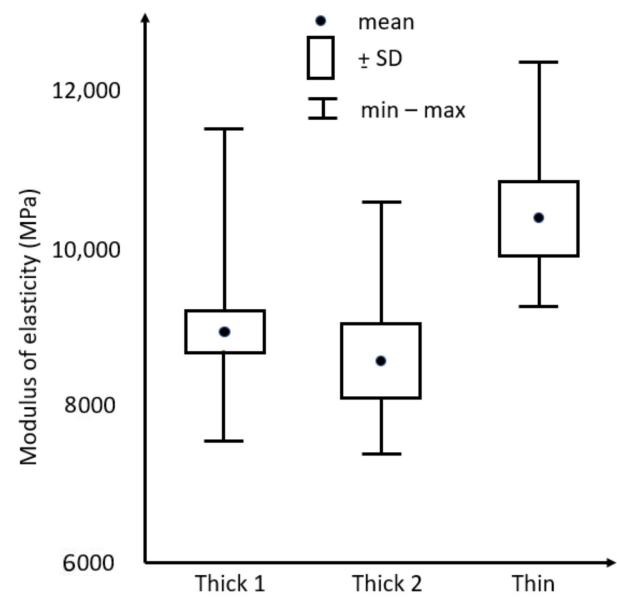

(a)

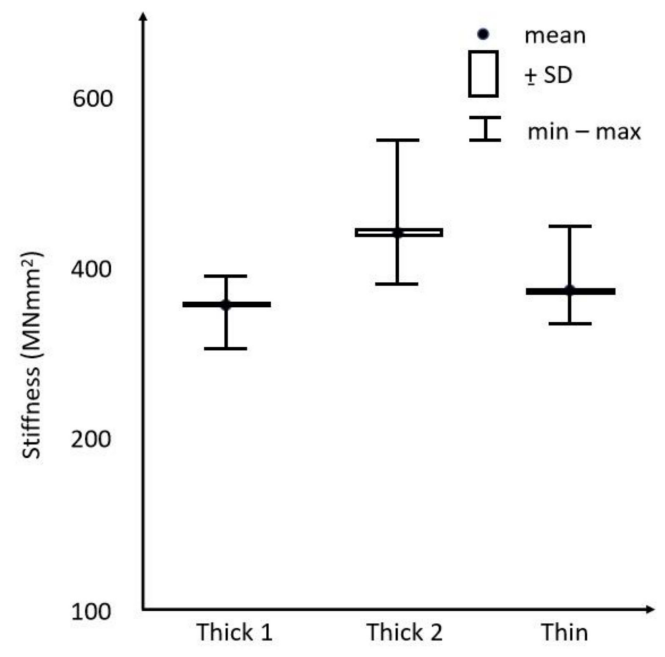

(b)

Figure 5. Results of static bending after conditioning under conditions of $22{ }^{\circ} \mathrm{C}$ and $50 \%$ air humidity: MOE (a), stiffness (b).

Laminated materials made of thinner veneers have more favorable mechanical properties (higher modulus of elasticity and bending strength) than composites of the same final thickness made of thicker veneers. This is due to the circumferential cutting mechanism, increasing the number and range of defects together with increasing the thickness of material. Cracks from the knife rake face, uneven veneer thickness, and surface roughness are particularly important. However, static bending tests have shown that the thicker the veneer (as layers of laminated composite), the higher its final stiffness properties, which especially matters in the case of floating floors.

The modulus of elasticity and stiffness generally is influenced by the quality of the material used [26]. In the case of low-quality base material ( $C$ and $D$ quality class of pine veneer according to [25]), the mean value of modulus of elasticity of the seventh layered composite panel was $9500 \mathrm{MPa}$, and the stiffness was $375 \mathrm{MNmm}^{2}$. The obtained test results for the engineering flooring material made of thicker veneers show similar values of these properties. It proves that it is possible to produce the composites from thicker veneers without reducing its final physical and mechanical properties.

The testing program assumed determination of static bending strength under conditions corresponding to the summer and winter seasons (Figure 6). Tests have shown that the commercially available composites are characterized by an average static bending strength equal to $45 \mathrm{MPa}$ (in dry conditions- $\mathrm{T}=22{ }^{\circ} \mathrm{C}$ and air humidity $10 \%$ ), and $42 \mathrm{MPa}$ (in humid conditions- $\mathrm{T}=22{ }^{\circ} \mathrm{C}$ and air humidity $80 \%$ ). The produced composites (thick 1 , thick 2 , and thin) conditioned in $80 \%$ air humidity conditions show a higher average value of static bending strength than the commercially available composites. When taking into account quality of the base layer (B, C, D) [26], it can be found that the static bending strength of the samples ranged from 52 to $60 \mathrm{MPa}$. When testing the conditioned samples under humid conditions, these values were lower by about $5 \%$. 


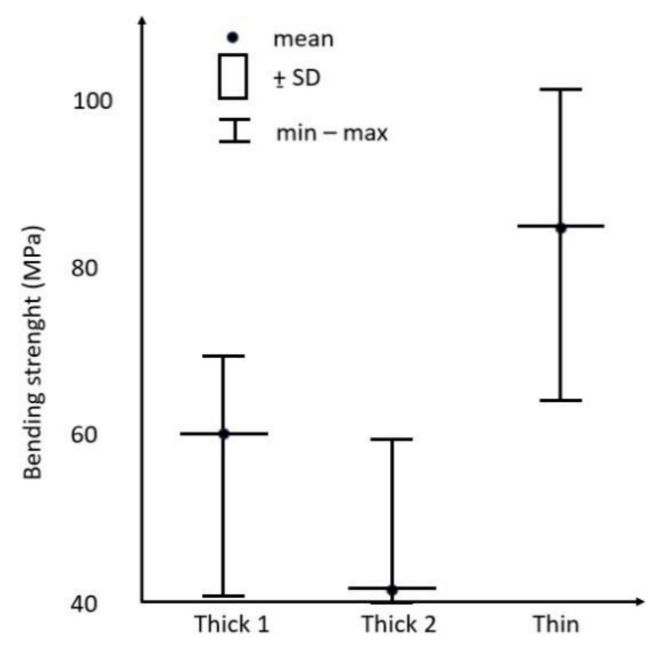

(a)

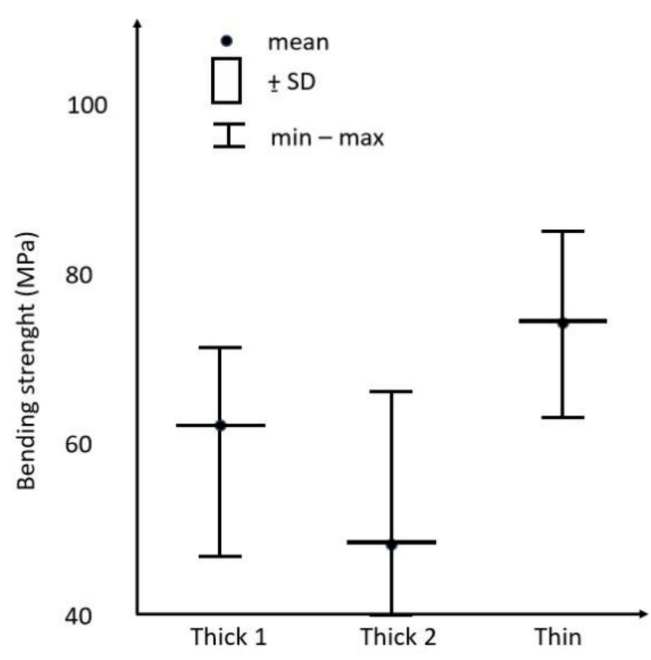

(b)

Figure 6. Results of static bending strength under conditions of $22{ }^{\circ} \mathrm{C}$ and air humidity: $10 \%$ (a), $80 \%$ (b).

Figures 7 and 8 show the results of testing the modulus of elasticity and stiffness in dry $\left(22^{\circ} \mathrm{C}\right.$ and $10 \%$ air humidity) and humid $\left(22{ }^{\circ} \mathrm{C}\right.$ and $80 \%$ air humidity) conditions. The highest value of the modulus of elasticity was achieved when the base layer of samples consisted of pine veneers with a thickness of 1.5-2.5 mm. A greater number of base layers translates into a greater number of adhesive joints, which results in a greater modulus of elasticity achieved in case of both dry and humid conditions. In the case of commercially available composites, the following values were obtained: average modulus of elasticity $8120 \mathrm{MPa}$ and stiffness $333 \mathrm{MNmm}^{2}$ (for dry conditions $-22{ }^{\circ} \mathrm{C}$ and $10 \%$ air humidity), and $7010 \mathrm{MPa}$ and $287 \mathrm{MNmm}^{2}$ (for humid conditions $-22{ }^{\circ} \mathrm{C}$ and $80 \%$ air humidity) [38].

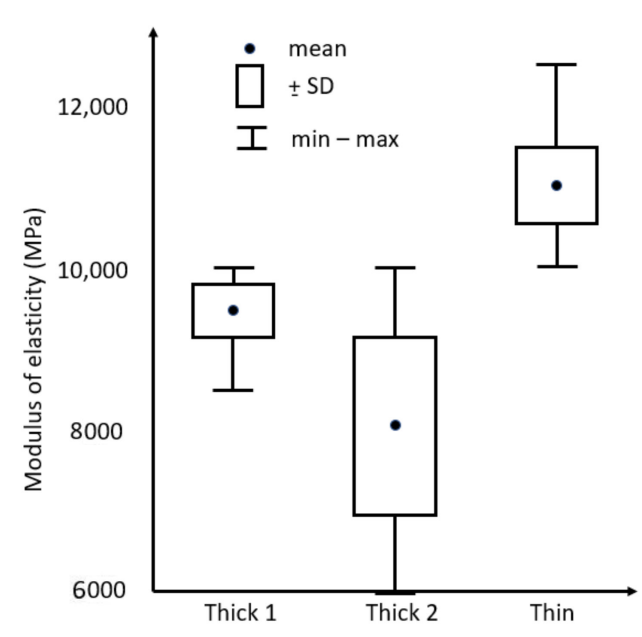

(a)

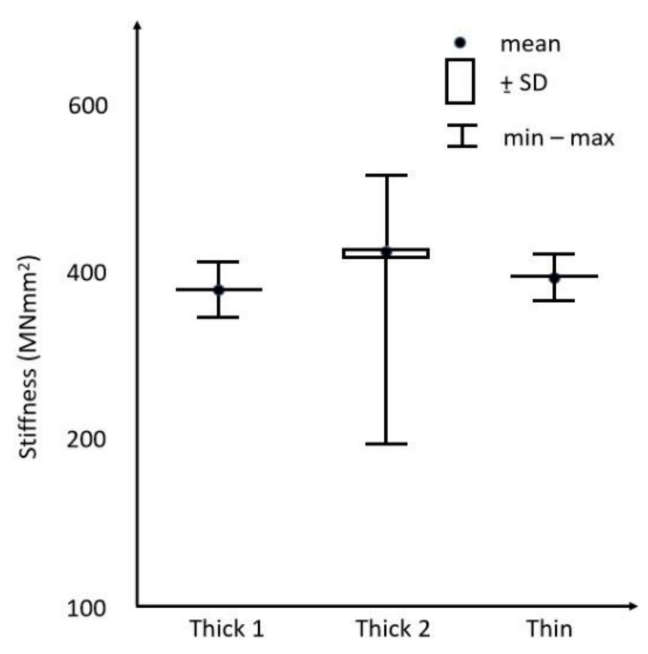

(b)

Figure 7. Results of fatigue in bending after conditioning under conditions of $22{ }^{\circ} \mathrm{C}$ and $10 \%$ air humidity: MOE (a), stiffness (b). 


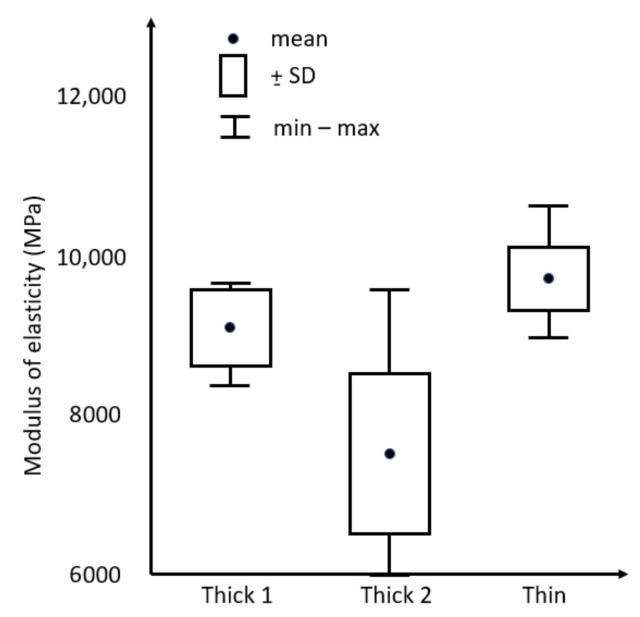

(a)

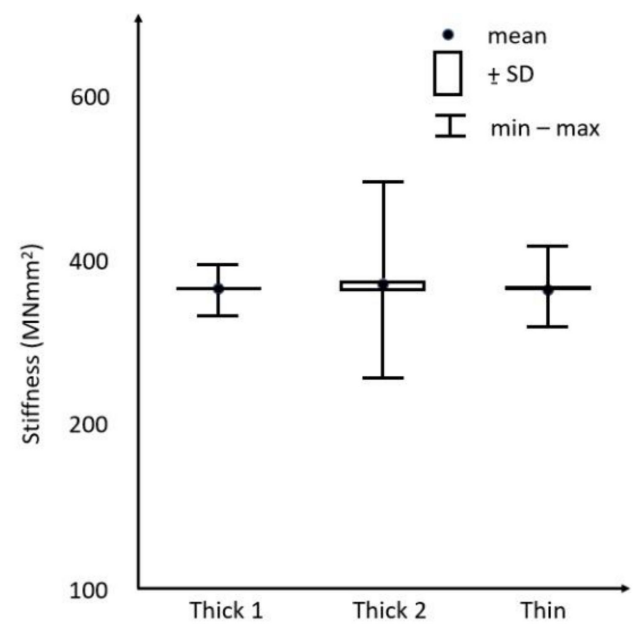

(b)

Figure 8. Results of fatigue in bending after conditioning under conditions of $22{ }^{\circ} \mathrm{C}$ and $80 \%$ air humidity: MOE (a), stiffness (b).

\subsection{Dynamic Bending}

The results of dynamic bending tests by means of modulus of elasticity and stiffness are presented in Figure 9. The values of the modulus of elasticity and stiffness of composites obtained in the dynamic test are analogous to those obtained in the static test. In this case, the obtained values are also higher than for commercially available composites $(7400 \mathrm{MPa}$, $280 \mathrm{MNmm}^{2}$, respectively) [38,39].

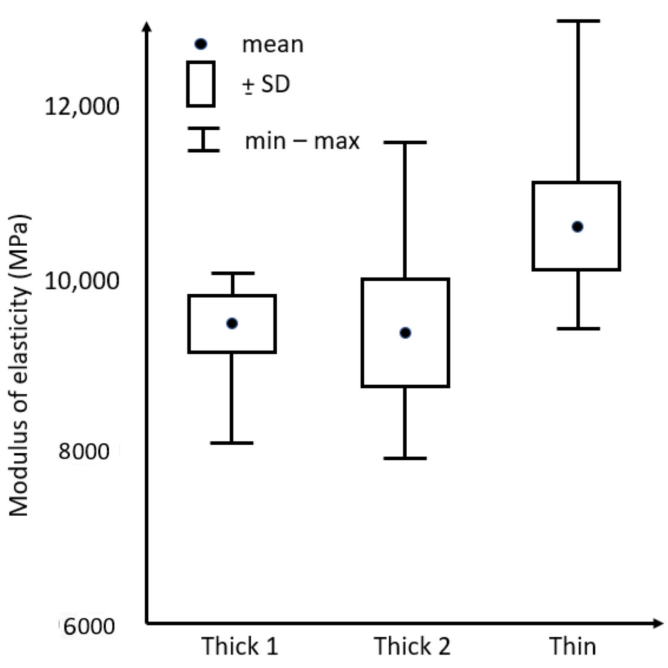

(a)

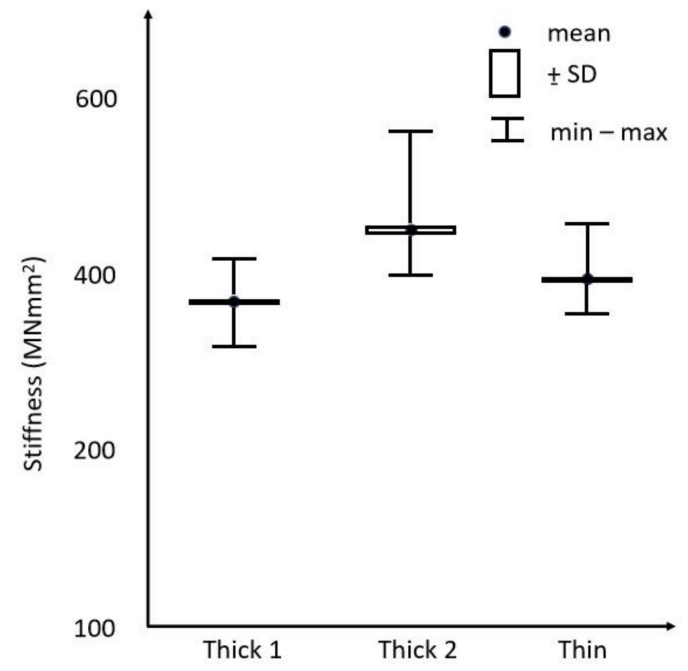

(b)

Figure 9. Results of dynamic bending after conditioning under conditions of $22{ }^{\circ} \mathrm{C}$ and $50 \%$ air humidity: MOE (a), stiffness (b).

\subsection{Fatigue Bending}

With the subsequent cycles $(1,10,20,30,40,50$ cycles), no relevant differences were noticed in the obtained values of the modulus of elasticity and stiffness. This is most likely due to the cross-veneers used in the base layer. The commercially available composite, with the outer layer made of longitudinal lamellae, was destroyed in the first cycles of the fatigue test [38]. The average results of the modulus of elasticity and stiffness obtained during the fatigue test are shown in Figure 10. Noteworthy is the low value of the modulus 
of elasticity obtained for composites made of the thickest veneer (Thick 2). This is due to the greater number of defects related to the circumferential machining process. It is worth noting that defects caused by circumferential cutting do not affect the stiffness values as much.

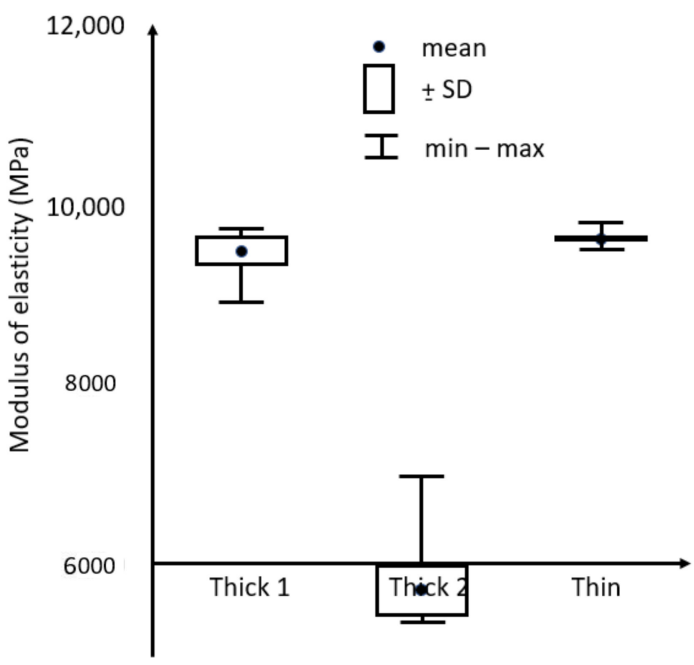

(a)

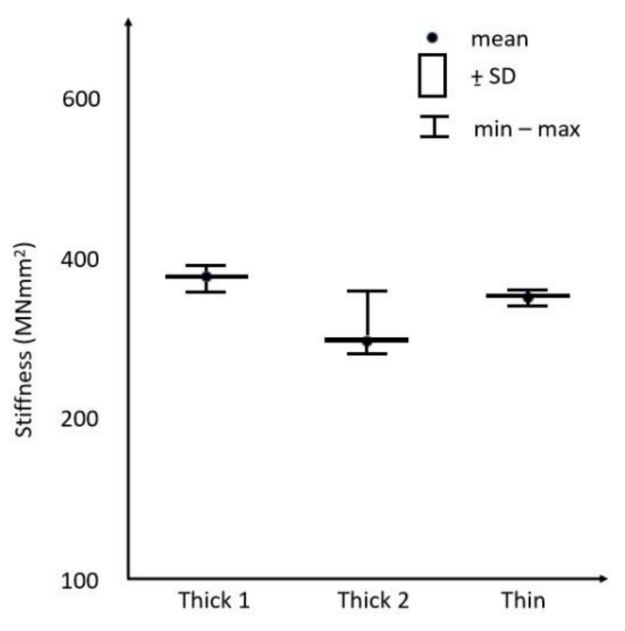

(b)

Figure 10. Results of fatigue in bending after conditioning under conditions of $22{ }^{\circ} \mathrm{C}$ and $50 \%$ air humidity: MOE (a), stiffness (b).

\section{Conclusions}

The production of flooring materials from veneers in the plywood-like structure in the base layer showed that the higher thickness of veneers affects the modulus of elasticity and stiffness in a negligible way. In the base layer, four layers can be used instead of six. Of course, the optimization of the technological peeling process is needed, which will probably improve the repeatability of the physical and mechanical properties of the produced composites. The use of thicker veneers in the base layer of the plywood-like structure shows increased strength to static and dynamic loads relative to a commercial composite with inner layer in the form of arranged lamellae. Despite the fact that the research was cognitive, piloting the results indicates a large potential for saving materials, aiding in the protection of the environment and increasing the productivity of enterprises.

Author Contributions: Conceptualization, I.B.-K. and P.B.; methodology, I.B.-K. and P.B.; software, I.B.-K. and P.P.; validation, I.B.-K. and P.B.; formal analysis, I.B.-K., P.P., and P.B.; investigation, P.P.; resources, I.B.-K. and P.B.; data curation, P.P. and P.B.; writing—original draft preparation, I.B.-K. and P.B.; writing-review and editing, I.B.-K. and P.B.; visualization, I.B.-K. and P.P.; supervision, P.B.; project administration, P.B.; funding acquisition, I.B.-K. and P.B. All authors have read and agreed to the published version of the manuscript.

Funding: This research was funded by the National Centre for Research and Development and the Warsaw University of Life Sciences-SGGW, grant number No BIOSTRATEG2/298950/1/NCBR/2016.

Institutional Review Board Statement: Not applicable.

Informed Consent Statement: Not applicable.

Data Availability Statement: Not applicable.

Acknowledgments: The authors are grateful for the support of the National Centre for Research and Development, Poland, under "Environment, agriculture and forestry"-BIOSTRATEG strategic R\&D program, agreement No BIOSTRATEG2/298950/1/NCBR/2016 (because entrepreneurs took part in the project, some of the information was confidential). 
Conflicts of Interest: The authors declare no conflict of interest.

\section{References}

1. Blanchet, P.; Beauregard, R.; Cloutier, A.; Gendron, G.; Lefebvre, M. Evaluation of Various Engineered Wood Flooring Constructions. For. Prod. J. 2003, 53, 30-37.

2. Gungor, N.M.; Kurtoglu, A.; Korkut, S. Solid Wood Flooring and Multilayered Parquet Industries in Turkey. Sci. Res. Essays 2009, 4, 1243-1247.

3. Aksamija, A. Comparative Analysis of Flooring Materials: Environmental and Economic Performance. Perkins+Will Res. J. 2010, 2, 55-66.

4. Barlinek, S.A. Barlinek Engineered Wood Flooring. Available online: https://www.barlinek.co.uk/products/engineered-woodflooring/ (accessed on 7 January 2022).

5. Kaczkan Premium Wooden Floors. Available online: https://kaczkan.com/en/our-floors/wood-finishing/ (accessed on 7 January 2022).

6. Global Wood. Available online: http:/ / www.globalwood.be/aanbod/assortiment/ (accessed on 7 January 2022).

7. Blanchet, P. Long-Term Performance of Engineered Wood Flooring When Exposed to Temperature and Humidity Cycling. For. Prod. J. 2008, 58, 37-44.

8. Borysiuk, P.; Burawska-Kupniewska, I.; Auriga, R.; Kowaluk, G.; Kozakiewicz, P.; Zbiec, M. Influence of Layered Structure of Composite Timber Floor Boards on Their Hardness. Drv. Ind. 2019, 70, 399-406. [CrossRef]

9. Heräjärvi, H. Variation of Basic Density and Brinell Hardness within Mature Finnish Betula Pendula and B. Pubescens Stems. Wood Fiber Sci. 2004, 36, 216-227.

10. Holmberg, H. Influence of Grain Angle on Brinell Hardness of Scots Pine (Pinus sylvestris L.). Holz Roh-Und Werkst. 2000, 58, 91-95. [CrossRef]

11. Song-Yung, W.; Hon-Lin, W. Effects of Moisture Content and Specific Gravity on Static Bending Properties and Hardness of Six Wood Species. J. Wood Sci. 1999, 45, 127-133.

12. Grześkiewicz, M.; Krawiecki, J. Thermally Modified Ash and Oak Wood as Materials for Parquets-Mechanical Properties of the Wood and Its UV Resistance for Different Kinds of Wood Finishing. Ann. WULS—SGGW For. Wood Technol. 2008, 65, 93-97.

13. Esteves, B.M.; Pereira, H.M. Wood Modification by Heat Treatment: A Review. BioResources 2009, 4, 370-404. [CrossRef]

14. Herrera-Builes, J.F.; Sepúlveda-Villarroel, V.; Osorio, J.A.; Salvo-Sepúlveda, L.; Ananías, R.A. Effect of Thermal Modification Treatment on Some Physical and Mechanical Properties of Pinus Oocarpa. Wood. For. 2021, 12, 249. [CrossRef]

15. Xiaoyan, Y.; Dandan, X.; Yan, S.; Yuran, G.; Jilong, F.; Xiaohan, D.; Zaixin, H.; Xiaoying, D.; Yufeng, D.; Yongfeng, L. Preparation of Wood-Based Panel Composites with Poplar Veneer as the Surface Layer Modified by In-Situ Polymerization of Active Monomers. Forests 2020, 11, 893.

16. Kamke, F.A.; Zylkowski, S.C. Effect of Wood-Based Panel Characteristics on Thermal Conductivity. For. Prod. J. 1989, 52, 75-83.

17. Seo, J.; Jeon, J.; Lee, J.-H.; Kim, S. Thermal Performance Analysis According to Wood Flooring Structure for Energy Conservation in Radiant Floor Heating Systems. Energy Build. 2011, 43, 2039-2042. [CrossRef]

18. Rozins, R.; Iejavs, J. Evaluation of Thermal Properties of Wood Based Composite Panel Walls. Res. Rural Dev. 2014, 2, 109-114.

19. Zhang, L.; Huang, X.; Liang, L.; Liu, J. Experimental Study on Heating Characteristics and Control Strategies of Ground Source Heat Pump and Radiant Floor Heating System in an Office Building. Proced. Eng. 2017, 205, 4060-4066. [CrossRef]

20. Pajchrowski, G.; Noskowiak, A. Thermal Conductivity of Wooden Floors in the Context of Underfloor Heating System Applications. Drewno 2018, 61, 145.

21. Makowski, A.; Noskowiak, A. Empirical Verification of a Digital Model of a Basketball to Assess Elastic Properties of Sports Floors. Ann. WULS-SGGW For. Wood Technol. 2016, 95, 227-230.

22. Kallakas, H.; Rohumaa, A.; Vahermets, H.; Kers, J. Effect of Different Hardwood Species and Lay-up Schemes on the Mechanical Properties of Plywood. Forests 2020, 11, 649. [CrossRef]

23. Beer, P.; Pacek, P.; Burawska-Kupniewska, I.; Oleńska, S.; Różańska, A. Influence of Alder (Alnus Glutinosa Gaerthn.) Veneers on Selected Mechanical Properties of Layered Pine (Pinus sylvestris L.) Composites. Ann. WULS—SGGW For. Wood Technol. 2019, 108, 13-20. [CrossRef]

24. Byczek, M.; Borysiuk, P. Impact of the Quality on the Properties of the LVL. Ann. Wars. Univ. Life Sci. SGGW For. Wood Technol. 2017, 99, 132-142.

25. EN 1927-2:2008. Qualitative Classification of Softwood Round Timber_Part 2: Pines; iTeh Standards: Toronto, ON, Canada, 2008.

26. Burawska-Kupniewska, I.; Mycka, P.; Beer, P. Influence of Scots Pine (Pinus sylvestris L.) Veneers Quality on Selected Properties of Layered Composite for Flooring Materials. Forests 2021, 12, 1017. [CrossRef]

27. Lee, C.H.; Chung, M.J.; Lin, C.H.; Yang, T. Effects of Layered Structure on the Physical and Mechanical Properties of Laminated Moso Bamboo (Phyllosachys Edulis) Flooring. Constr. Build. Mater. 2012, 28, 31-35. [CrossRef]

28. Barlinek, S.A. Barlinek Floor in Your Architectural Inferior. Available online: https://www.barlinek.com.pl (accessed on 22 November 2021).

29. Paged Morag, S.A. Synergy of Nature and Technology. Available online: https://sklejkapaged.pl/en/contact/ (accessed on 20 August 2021). 
30. Sieć Badawcza Łukasiewicz-Instytut Technologii Drewna. Available online: https://www.itd.poznan.pl/pl/vademecum/sosna (accessed on 20 August 2021).

31. Centre Technique du Bois et de l'Ameublement (CTBA). Available online: https://data.bnf.fr/fr/11871779/centre_technique_ du_bois_et_de_1_ameublement_paris / (accessed on 20 August 2021).

32. Jaka Jest Optymalna Temperatura i Wilgotność w Domu? Available online: https://goodair.pl/blog/temperatura-i-wilgotnoscwdomu (accessed on 11 April 2021).

33. EN 310:1994. Wood-Based Panels-Determination of Modulus of Elasticity in Bending and of Bending Strength; European Committee for Standardization: Brussels, Belgium, 1994.

34. ISO 9052-1. Determination of Dynamic Stiffness. Part 1-Materials Used under Floating Floors in Dwellings; ISO: Geneva, Switzerland, 1989.

35. European Commission; Communication from the Commission to the European Parliament; The Council; The European Economic and Social Committee; The Committee of the Regions. Sustainable Europe Investment Plan. European Green Deal Investment Plan; European Commission: Brussels, Belgium, 2020. Available online: https:/ / eur-lex.europa.eu/legal-content/EN/TXT/HTML/ ?uri=CELEX:52020DC0021\&from=EN (accessed on 11 April 2021).

36. European Commission; ANNEX to the Communication from the Commission to the European Parliament; The European Council; The Council; The European Economic and Social Committee; The Committee of the Regions. The European Green Deal; European Commission: Brussels, Belgium, 2019. Available online: https://ec.europa.eu/info/sites/default/files/europeangreen-dealcommunication-annex-roadmap_en.pdf (accessed on 11 April 2021).

37. European Commission. Circular Economy Action Plan. For a cleaner and more competitive Europe. In New Circular Economy Action Plan; European Commission: Brussels, Belgium, 2020. Available online: https://ec.europa.eu/environment/strategy/ circulareconomy-action-plan_en (accessed on 11 April 2021).

38. Pacek, P. Influence of the Thickness of Veneers on Selected Properties of Layered Composites. Master's Thesis, Warsaw University of Life Science, Faculty of Wood Technology, Warsaw, Poland, 2019. (In Polish)

39. Barlinek, S.A. Deska Barlinecka. Available online: https://www.barlinek.com.pl/deska-barlinecka-warstwowa/ (accessed on 10 October 2019). 